OPEN ACCESS

Citation: Wong Sin Yeng, Peter C. Boyce (2021) Studies of the Homalomeneae (Araceae) of Peninsular Malaysia VII: Homalomena puncticulosa [Chamaecladon Clade], a new species from recreational forest. Webbia. Journal of Plant Taxonomy and Geography 76(2): 261-264. doi: 10.36253/jopt-11500

Received: July 15, 2021

Accepted: July 25, 2021

Published: September 7, 2021

Copyright: @2021 Wong Sin Yeng, Peter C. Boyce. This is an open access, peer-reviewed article published by Firenze University Press (http://www. fupress.com/webbia) and distributed under the terms of the Creative Commons Attribution License, which permits unrestricted use, distribution, and reproduction in any medium, provided the original author and source are credited.

Data Availability Statement: All relevant data are within the paper and its Supporting Information files.

Competing Interests: The Author(s) declare(s) no conflict of interest.

Editor: Alistair Hay

ORCID

WSY: https://orcid.org/0000-0003-40429672

PCB: https://orcid.org/0000-0002-58569561

\section{Studies of the Homalomeneae (Araceae) of Peninsular Malaysia VII: Homalomena puncticulosa [Chamaecladon Clade], a new species from recreational forest}

\author{
Wong Sin Yeng ${ }^{1,2,3, *}$, Peter C. Boyce ${ }^{3}$ \\ ${ }^{1}$ Institute of Biodiversity and Environmental Conservation, Universiti Malaysia Sarawak \\ 94300 Kota Samarahan, Sarawak, Malaysia \\ ${ }^{2}$ Harvard University Herbaria, 22 Divinity Avenue, Cambridge, MA 02138, USA \\ ${ }^{3}$ Department Biologie I, Systematische Botanik und Mykologie, Ludwig-Maximilians- \\ Universität München, München, Germany \\ *Corresponding author. E-mail: sywong@unimas.my
}

\begin{abstract}
Homalomena puncticulosa is described and illustrated as a new species of the Chamaecladon Clade known from a single population in Selangor, and compared with the superficially similar H. kiahii Furtado, and other similar Sumateran species.
\end{abstract}

Keywords: Homalomena Chamaecladon Clade, taxonomy, Selangor, Triassic granite.

\section{INTRODUCTION}

During fieldwork in recreational forest, which is to say forest that has continual public access for recreational activities such as mountain biking, swimming, etc., on the fringe of the protected Taman Negeri Selangor, a population of a facultatively rheophytic Chamaecladon clade Homalomena was encountered that aroused interest by having the petioles and the spathe exterior longitudinally ribbed, a characteristic previously unrecorded for the genus in the Malay Peninsula. At the time of collecting, all blooms were post-anthesis and, although the spathes were highly characteristic, the critical spadix characteristics were unobservable. Plants bought into cultivation subsequently flowered and, as discussed below, confirmed that the plants indeed did not match any of the species described for Peninsular Malaysia.

As noted in previous papers (Baharuddin and Boyce 2005, 2010, 2011, Boyce and Wong 2017; Wong and Boyce 2021; Zulhazman et al. 2011, 2012) Homalomena remains least well-studied large genus of Asian Araceae, within which species of the Chamaecladon clade (Wong et al. 2013) are perhaps the most poorly understood.

Geological occurrences in this paper are verified with Tate et al. (2008). 
Homalomena puncticulosa S.Y.Wong \& P.C.Boyce sp. nov.

Type: Cultivated Buso, Bau, Kuching [original collection: Malaysia. Selangor, Batu Caves, Jalan Sungai Tua, Kampung Pasir Ulu Yam, Taman Negeri Selangor, Sungai Tua, 318'44.28”N 101²4'57.46”E, $160 \mathrm{~m}$ asl., 6 Jun 2011, P.C.Boyce, Wong Sin Yeng \& April Ting Pei Jen AR-3590 (holotype KEP!; isotype KEP - spirit). (Figure 1).

\section{Diagnosis}

Homalomena puncticulosa differs from all other described species occurring in Peninsular Malaysia by the pistils with conspicuous red punctations, and by the longitudinally ribbed petioles and spathe limb exterior. Sterile plants are similar in overall appearance to $\mathrm{H}$. kiahii, notably by the proportionately (to the blade length) short petioles, but immediately distinguished by the ribbed petiole. From species in Sumatera in which the spathe exterior and/or petioles are longitudinally ribbed (H. mobula and H. plicata) H. puncticulosa is distinguished by the leaf blades smooth, not adaxially ornamented, and by pistils with red punctations.

\section{Description}

Small slightly aromatic (terpenoids) facultatively rheophytic herbs to c. $20 \mathrm{~cm}$ tall. Stem epigeal, erect or rooting-ascending, rooting from the nodes and through the petiole bases, new shoots flushed reddishbrown, later becoming green, older portions of stems medium brown; roots c. 1-2 $\mathrm{mm}$ diameter, tough, flexuous, pale brown, younger portions velvety. Leaves numerous, petioles erect, older ones slightly spreading with the blades held more or less flat; petiole 4-11 $\mathrm{cm}$ long, c. $2 \mathrm{~mm}$ diameter midway, dorsally narrowly channelled, pale green suffused with reddish brown, notably in the lower half, conspicuously longitudinally acute-ribbed; petiolar sheath $1.5-4 \mathrm{~cm}$ long, extending c. one-half length of the longest petiole, clasping at the base, width between both margins c. $2 \mathrm{~mm}$, wings persistent, tips truncate; leaf blade narrowly elliptic, 6-15 $\mathrm{cm}$ long, 3-4 cm wide, thinly coriaceous, dark matte medium green adaxially, noticeably paler matte green abaxially, base cuneate, apex acuminate with a short (c. $2 \mathrm{~mm}$ long) tubule, margins smooth; midrib adaxially almost flush with the blade, abaxially prominent with the basal half reddish brown; primary lateral veins $c$. 8 on each side of midrib, adaxially impressed, abaxially slightly prominent, diverging at c. $35-60^{\circ}$ from the midrib, alternating with much fainter regularly interspersed interprimaries; secondary venation faint, striate; tertiary venation almost invisible; all veins running into a slightly thickened intramarginal vein. Blooms up to seven produced sequentially in a simple synflorescence; peduncle terete, slender, $2-3 \mathrm{~cm}$ long, c. $2 \mathrm{~mm}$ diameter, reddish brown to reddish maroon, microscopically glandular-pubescent; spathe oblong ellipsoid, not constricted, c. $2 \mathrm{~cm}$ long, $8 \mathrm{~mm}$ wide at base, with a terminal short stout mucro to c. $2 \mathrm{~mm}$ long, exterior longitudinally ribbed, with the dorsal median rib forming a sharp keel that extends from the spathe down the peduncle, spathe inflating at anthesis with the margins spreading slightly, then closing post staminate anthesis and persisting until basal dehiscence at fruit dispersal, exterior matte reddish brown, visible exterior microscopically glandular-pubescent, with the portion of the exterior formerly hidden by the overlapping margin on opening exposed and glossy, interior similarly coloured to exterior but wholly glossy, margins hyaline. Spadix sub-equalling spathe limb at opening, c. $2 \mathrm{~cm}$ long, c. $3.5 \mathrm{~mm}$ diameter at mid-point, very briefly stipitate, stipe c. $0.5 \mathrm{~mm}$ long, smooth, very pale pink with a few minute red speckles; pistillate floret zone c. $5 \mathrm{~mm}$ long; pistils congested, stoutly bottle-shaped, c. $2 \mathrm{~mm}$ tall $\times 1 \mathrm{~mm}$ diameter, olive green with numerous scarlet speckles, style about $1 \mathrm{~mm}$ long, stout, stigma capitate, slightly wider than the style, c. $0.4 \mathrm{~mm}$ diameter, olive green; each pistil with a single staminode situated on proximal side of the floret relative to the base of the spadix; interpistillar staminodes oblong fusiform, c. 0.5 $\mathrm{mm}$ long, waxy white; staminate flower zone c. $1.5 \mathrm{~cm}$ long, stoutly oblong-conical, apex blunt; staminate florets well-defined, each consisting of two, occasionally three stamens, stamens rounded, c. $0.5 \mathrm{~mm}$ tall, $1-1.5$ $\mathrm{mm}$ long $\times 0.5-0.9 \mathrm{~mm}$ wide, creamy white with the thecae tips slightly transparent. Infructescence, fruit and seed not observed.

\section{Etymology}

The specific epithet puncticulosa is from the Latin meaning, minutely dotted, referring to the scarlet speckles on the pistils.

\section{Distribution and ecology}

So far known only from recreational forest abutting the Taman Negeri Selangor where it occurs as a facultative rheophyte on heavily shaded forested stream-edge Triassic granite rocks at low altitudes.

\section{Notes}

In Peninsular Malaysia Homalomena puncticulosa is most similar in overall appearance to Johore H. kiahii Furtado (1937: 207), although readily differentiated by the ribbed petioles. Although there are species of 


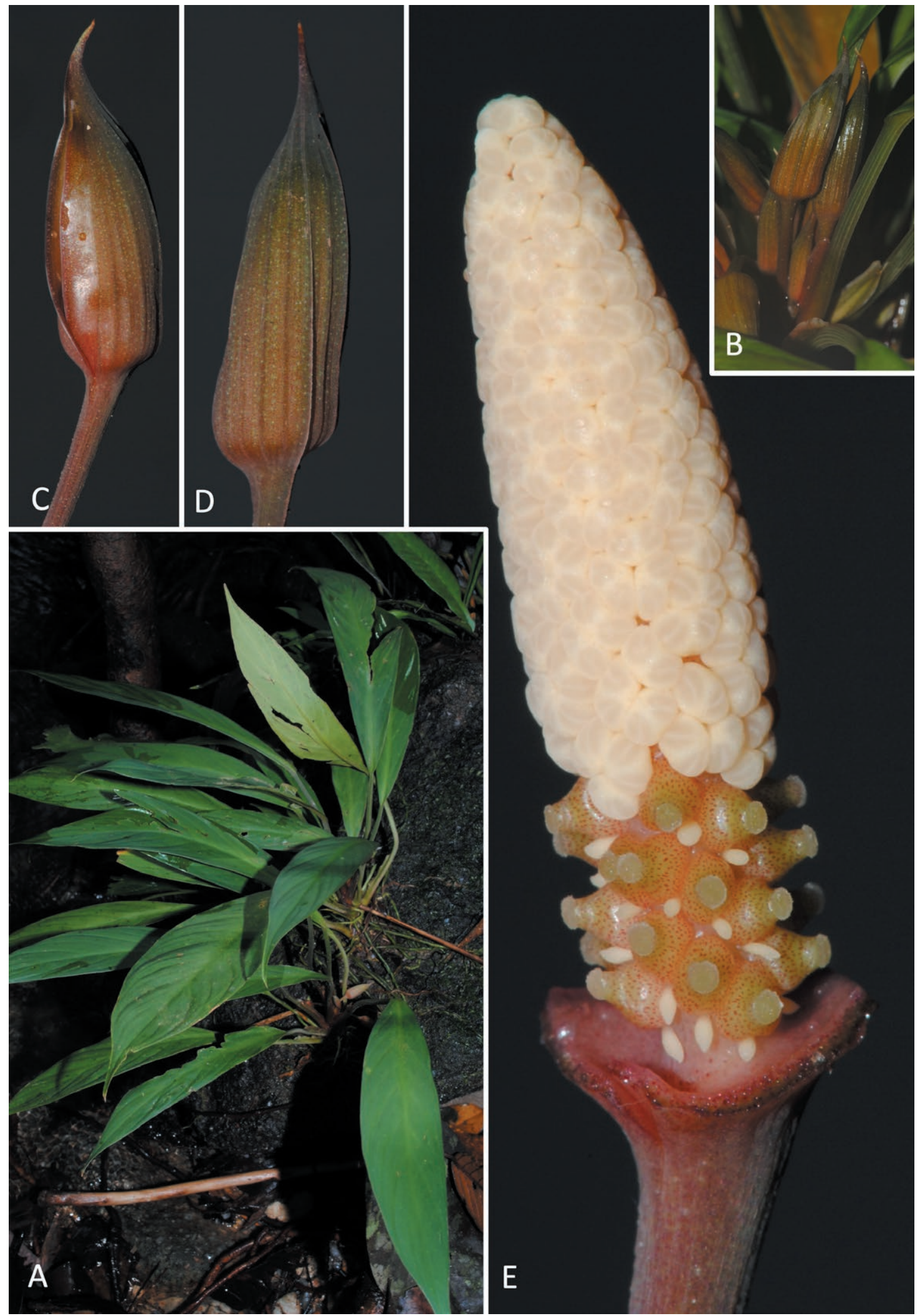

Figure 1. Homalomena puncticulosa (A) Plant in habitat. (B) Flowering shoot showing externally ribbed spathes and petioles. (C) and (D) Bloom at pistillate anthesis. (E) Spadix at pistillate anthesis, spathe artificially removed. All from AR-3590. 
Homalomena Chamaecladon clade with spathes externally ribbed occurring on Sumatera (among them $H$. mobula P.C.Boyce \& S.Y.Wong and H. plicata P.C.Boyce \& S.Y.Wong (Boyce \& Wong 2016: 254, 257) these have distinctly elaborated leaf blades or leaf epidermis quite different to these Selangor plants. Elsewhere in Sumatera Homalomena puncticulosa resembles $H$. batoeensis Engl. (Engler 1912: 47) and H. multivenosa Ridl. (Ridley 1926: 92) from the islands to the west of Sumatera, both of which have the spathe conventionally smooth on the outside, and unribbed petioles, differing further from the latter by leaf blades with far fewer primary lateral veins.

\section{ACKNOWLEDGEMENTS}

The second author extends his thanks to Tan Sri Datuk Amar Leonard Linggi Anak Jugah and Malesiana Tropicals Sdn Bhd for continued support and encouragement.

\section{REFERENCES}

Baharuddin S, Boyce PC. 2005. A remarkable new species of Homalomena (Araceae: Homalomeneae) from Peninsular Malaysia. Gardens' Bulletin Singapore. 57(1): 7-11.

Baharuddin S, Boyce PC. 2010. Studies on Homalomeneae (Araceae) of Peninsular Malaysia I: Homalomena asmae, a new species from Perak. Acta Phytotaxonomica et Geobotanica. 60(3): 163-166.

Baharuddin S, Boyce PC. 2011. Studies on Homalomeneae (Araceae) of Peninsular Malaysia V: Homalomena wallichii, refound after more than 190 years. Aroideana. 34: 24-29.

Boyce PC, Wong SY. 2016. Studies on Homalomeneae (Araceae) of Sumatera IV: Three new ornamental Homalomena (Chamaecladon clade) species. Willdenowia. 46(2): 253-260.

Boyce PC, Wong SY. 2017. Studies on Homalomeneae (Araceae) of Peninsular Malaysia VI - Homalomena electra, a new species and the first non-Bornean occurrence of the Hanneae Complex. Aroideana. 49(3): 4-14.

Engler A. 1912. Homalomeninae und Schismatoglottidinae. In A. Engler \& K. Krause, Araceae-Philodendroideae-Philodendreae. Das Pflanzenreich 55(IV.23Da): 1-134. Wilhelm Engelmann, Leipzig.

Furtado CX. 1939. Araceae Malesicae: Notes on some Indo-Malaysian Homalomena Species. Gardens' Bulletin Straits Settlements. 10(2): 183-238.
Ridley HN. 1926. The Flora of the Mentawi Islands. In C. Boden Kloss, Spolia Mentawiensia. Bulletin of Miscellaneous Information (Royal Botanic Gardens, Kew) 1926(2): 56-94.

Tate RB, Tan DNK, Ng TF. 2008. Geological Map of Peninsular Malaysia. Scale 1:1,000,000. Geological Society of Malaysia and University of Malaya.

Wong SY, Tan PJ, Ng KK, Ahmad Sofiman O, Lee HB, Fasihuddin BA, Boyce P.C. 2013. Phylogeny of Asian Homalomena (Araceae) based on the ITS Region Combined with Morphological and Chemical Data. Systematic Botany. 38(3): 589-599.

Wong SY, Boyce PC. 2021. Studies of the Homalomeneae (Araceae) of Peninsular Malaysia VII - Homalomena joanneae [Chamaecladon Clade], a new locally endemic limestone obligated species. Webbia. 76(1): 77-81.

Zulhazman H, Boyce PC, Mashhor M. 2011. Studies on Homalomeneae (Araceae) of Peninsular Malaysia III: Homalomena kualakohensis, a new species from Kelantan. Acta Phytotaxonomica et Geobotanica. 61(1): 35-39.

Zulhazman H, Mashhor M, Boyce PC. 2012. Studies on Homalomeneae (Araceae) of Peninsular Malaysia IV: Homalomena stongensis, a remarkable new species endemic to Gunung Stong, Kelantan. Gardens' Bulletin Singapore. 64(2): 525-529. 